DOI: $10.31696 / 2618-7302-2020-1-12-32$

ГИПОТЕЗА О «ЗЕМАЕ ИЗАИЯНИЯ РЕКИ»:

К ПРЕАЫСТОРИИ 1-ГО ПОРОГА В КОНТЕКСТЕ ГИАРОАОГИИ СРЕАНЕГОАОЦЕНОВОГО НИАА. ЧАСТЬ II

(C) 2020

А. Б. Прусаков*

История реки Ниц началась в геологическую эпоху позАнего (мессинского) миоцена (Эониц, около 6 млн. мет назаА). Эволюционно предшествовавшие современному ГАавному Нилу потоки (Палеониц, Протониц, Прениц, Неонил) протекали в иных руслах, от которых вАоль края ЗапаАной пустыни остались многоярусные береговые террасы, и значительно превосходили его по полноводности. Свой сегодняшний сравнительно скромный (около 85 км$^{3}$ ) годовой объем стока в русле «финальной» конфигурации Нил приобрел, по-видимому, после так называемого «неолитического спада» во второй половине IV тыс. Ао н. э., или примерно в протодинастический период зарожАавшейся фараоновской цивилизации (Нагада III). В это время имело место территориацьное слияние Верхнего и Нижнего Египта, чему, по моей гипотезе, способствовало исчезновение «голоценового моря» - разАелявшего страну протяженного озера на Нияе, возникшего ориентировочно не раньше VII тыс. Ао н. э. в Среднем Египте межАу Асиутом и Фаюмом. Аревнейшие (Аатируемые с эпипалеолита) петроглифы в районе Гарб Асуана на западном берегу Реки у подножия «Сиенского катаракта» своим расположением (бассейны вади) и содержанием (прежде всего изображениями модок и крокодилов) наводят на мысль о заливах полноводного дельта-Неонила в ВаАи эль-Фарас и Аругих ныне сухих зАешних руслах, впадающих в нильскую Аолину. «Колцапс» петроглифики Гарб Асуана на начацьной стадии египетского государствогенеза мог быть связан с окончательным уходом отсюда воА Нила, отступивших с больших площадей протодинастического поречного Верховья, вкАючая область 1-го порога.

Ключевые слова: Ниц, геология, гихрология, 1-й порог, Нижняя Нубия, Верхний Египет, Гарб Асуан, петроглифы, голоцен, Аодинастический период, протодинастический периоА, архаический период.

Аля читирования: Прусаков А. Б. Гипотеза о «Земле измияния Реки»: к предыстории 1-го порога в контексте гидрологии среднеголоценового Нила. Часть II. Вестник Института востоковедения РАН. 2020. № 1. С. 12-32. DOI: 10.31696/2618-7302-2020-1-12-32

\footnotetext{
* Амитрий Борисович ПРУСАКОВ, Аоктор исторических наук, главный научный сотрудник Института востоковедения РАН, Москва; dmprusakov@mail.ru

Dmitry B. PROUSSAKOV, DSc (History), Principal Research Fellow, Institute of Oriental Studies RAS, Moscow; dmprusakov@mail.ru

ORCID ID: 0000-0001-6065-4610
} 


\section{THE HYPOTHESIS OF THE “LAND OF OUTPOURING OF THE RIVER”: ON THE PREHISTORY OF THE FIRST CATARACT IN THE CONTEXT OF HYDROLOGY OF THE MID-HOLOCENE NILE. PART II}

\section{Dmitry B. Proussakov}

The history of the River Nile began in the geological epoch of the upper (Messinian) Miocene (Eonile, about $6 \mathrm{Ma}$ ). Rivers that preceded evolutionarily the modern Main Nile (Paleonile, Protonile, Prenile, and Neonile) flowed in other channels which left behind them a number of terraces along the edge of the Western Desert, and surpassed it considerably in water volumes. The Nile acquired its hodiernal annual discharge of about $85 \mathrm{~km}^{3}$, in the "final" bed, apparently after the so-called "Neolithic drop" in the late Fourth millennium BC, or approximately in the Protodynastic Period of the emerging Pharaonic civilization (Naqada III). At that time, territorial integration of Upper and Lower Egypt was under way, facilitated, according to my hypothesis, by disappearance of the "Holocene sea", a large lake which arose in Middle Egypt between Asyut and Faiyum, tentatively, not earlier than the Seventh millennium BC. The oldest (dated from the Epipaleolithic) petroglyphs of Gharb Aswan on the west bank of the Nile at the foot of the First cataract, taking into account their location (wadi basins) and imagery (primarily, drawings of boats and crocodiles), make one think about bays of the more vigorous delta-Neonile in Wadi el-Faras and other now dry channels falling into the Nile Valley. "Collapse" of the Gharb Aswan rock art at the original phase of the Egyptian state formation may have been connected with recession of the Nile whose decreasing waters exposed large surfaces of Protodynastic Upper Egypt, including the First cataract region.

Keywords: the River Nile, geology, hydrology, the First cataract, Lower Nubia, Upper Egypt, Gharb Aswan, petroglyphs, Holocene, Predynastic Period, Protodynastic Period, Archaic Period.

For citation: Proussakov D. B. The Hypothesis of the "Land of Outpouring of the River": On the Prehistory of the First Cataract in the Context of Hydrology of the Mid-Holocene Nile. Part II. Vestnik Instituta vostokovedenija RAN. 2020. 1. Pp. 12-32. DOI: 10.31696/2618-7302-2020-1-12-32

еолого-гилрологическая история Нила исследовалась учеными давно (см.,
например: [Arldt, 1918; Blanckenhorn, 1902]) и максимально полно, вплоть
до позднего миоцена, когда водные потоки, стекавшие с дожАливых западных скцонов Этбая, начали сливаться в самостоятельную реку - Эониц, не связанную с глубинами африканского континента. Приточный «эфиопский» водосбор с озером Тана, Голубым Нилом и Атбарой к тому времени еще не сформировался, как и питающая сегодня Белый Ниц озерно-речная система экваториального плоскогорья, сток которого был направ ен в основном к бассейну Конго и Индийскому океану с наметившимся выходом на север, где на месте нынешней болотистой равнины СэдА простирался мегаводоем площадью в сотни тысяч кваАратных километров. Его и Аругие поверхностные воды черной Африки от Египта отделял высокий Нубийский массив, впоследствии испытавший тектоническое опускание и рассеченный пороговостремнинным отрезком нимьского русла от Хартума до Вади Хальфа [Said, 1962; 1981].

Эонил, зародившийся и развивавшийся как исключительно или преимущественно «египетская» река, пробивац себе магистральный путь к опустынивавшейся (см.: [Нsü, 1983]) средиземноморской котловине. В ту эпоху, 5,56 млн. мет назаА, Средиземное море катастрофически усохло (на какое-то время, повидимому, Ааже совсем исчезло, ср.: [Roveri et al., 2008]), Аишившись свободного 
сообщения с Атлантикой ${ }^{1}$ через Бетский и Рифский проливы, где произошел подъем земной коры, и испытав при этом критическое возАействие глобально нараставшей арилизации климата - еще не до конца изученный природно-геологический феномен, известный как Мессинский соленостный кризис (см., например: [Hsü, Ryan, Cita, 1973; Hsü et al., 1977]). Колоссальный объем испаряющейся морской воды обернулся обильными круглогодичными АОжАями в египетской Восточной пустыне, которые проложили от зАешних гор, существенно превышавших сохранившиеся от них Ао наших Аней «Красноморские холмы», густую сеть полноводных русел (сегодняшних реликтовых ваАи) и обеспечили стабильный речной сток к остаткам Средиземного моря [Said, 1993]. Его быстро ${ }^{2}$ и экстремально низко упавший уровень - базис эрозии

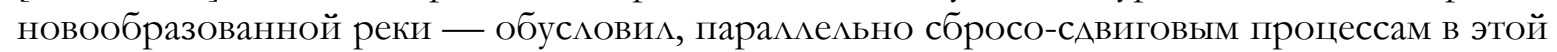
части верхнемиоценового Египта, интенсивное врезание Эоница до масштабов гигантского каньона ${ }^{3}$, Алиной и (ближе к устью) глубиной значительно превосходившего Гранд-Каньон Колорадо в Аризоне.

В начале плиоцена, около 5,3 млн. кет назаА, стремительная трансгрессия Средиземного моря, последовавшая за восстановлением ${ }^{5}$ его свободной гилрологической связи с Атлантическим океаном, превратила каньон в морской залив наподобие величественного фьорда протяженностью по крайней мере до Асуана, среАней шириной $\sim 12$ км, раскинувшего в отАельных вади рукава-ответв ения Алиной Ао 30 км (ср.: [Gargani, Rigollet, Scarselli, 2010; Little, 1936]). В верхнем плиоцене, около 2,6 млн. мет назаА, регрессирующий залив, уже основательно опресненный мивневым стоком Этбая, отступиц переА Рекой (Палеонил), причем, возможно, именно тогАа она, косвенно затронутая тектоническими движениями в рифтовой Восточной Африке, впервые сомкнулась на юге через суданский коридор с бассейном Белого Нила, вкАючая его притоки Бахр эль-Газаль и Собат (см.: [Hayes, 1965]) — точка зрения, оспаривавшаяся с указанием на недостаточность, в частности, водного фаунистического материала, способного ее подтвердить [Said, 1993].

\footnotetext{
1 А до того, 10-12 млн. мет назад, с Индо-Пацификой в ходе распада древнего океана Тетис (см., например: [von Rögl, Steininger, 1983]).

2 По некоторым расчетам, с окончательным закрытием упомянутых проливов море только за первые полторы тысячи Ает, геологически мгновенно, опустилось на 1500 м [Монин, Шишков, 1979; cp.: Rouchy, Caruso, 2006].

3 Обнаружен советским геологом И. С. Чумаковым при разведочных бурениях нильского можа переА строительством Высотной Асуанской плотины [Чумаков, 1967; Chumakov, 1973; см. также: Маловицкий и Ap., 1982].

4 По предварительным оценкам Р. Саида, Ано эонильского каньона у Асуана пролегало почти на 200 м ниже современного уровня моря, в районе Каира - более чем на 500 м, предельная же абсолютная глубина достигала 2,5 км [Said, 1976; 1981]. По его же позднейшим выкладкам на основе комплекса скважинных, сейсмических и гравиметрических данных, глубина каньона относительно уровня моря состав яяла 170 м у Асуана, 800 м у Асиута, 2500 м в районе Каира, где Аействовац крупный водопаА, и 4000 м у северного края Аельты [Said, 1993].

${ }^{5}$ Согласно геофизическим реконструкциям, имело вид чудовищного водопада высотой не менее 800 м с расходом в 400-500 Амазонок, который, снеся скальную перемычку у Гибралтара (вероятно, не без помощи сильного землетрясения), обрушился в средиземноморский резервуар, гАе вода могла прибывать с невиАанной скоростью свыше 10 м в сутки (т. н. Занклийский потоп) (см., например: [Garcia-Castellanos et al., 2009; McKenzie, 1999]).
} 
Эволюция Реки в плейстоцене лелится геологической наукой на три фазы, которым предшествовало пересыхание Палеонила около 1,8-2 млн. мет назаА, когАа в Египте установился гипераридный климат, превративший его в пустыню тотального выветривания, Аишенную почв, растительности и каких-либо водотоков. Река возрожАалась с разной силой в АОжАливые эпизоды слеАующего милАиона кет, поначалу, вероятно, как эфемерный ${ }^{6}$ поток — так называемый Протониц, чей маршрут обозначен песчано-галечниковыми отложениями от Нубии (северный Судан) до Средиземного моря в виде характерных террас к западу от Ни^а наших Аней: например, его наносами образована широкая гравийная равнина Аарб эль-Галмаба (формация ЭАфу), межашая на 35-40 м выше сегодняшней нильской поймы [Said, 1981].

Около 700-800 тыс. мет назал «умеренные» вариации Протонила сменил рекорАно многоводный Пренил, протекавший по левому краю современной Аолины (в Среднем Египте - западнее рукава Бахр-Юсуф), создавший в Фаюмской депрессии крупный водоем с зеркалом на 44 м выше нынешнего соленого озера Биркет Карун и отличавшийся мощными наносами, минеральный состав которых свидетельствует об установлении «полной связи» эволюционирующей Реки с Голубым Нилом и Атбарой (cp.: [Butzer, 1959a; Williams, Williams, 1980]). Этой «фазовой перестройке» способствовали Алительные и сложные геологические процессы, в ходе которых окончательно определился рельеф Эфиопского нагорья с озером Тана и устойчивым поверхностным стоком в нильский бассейн, и произошла деформация рифта Альбертин ${ }^{7}$, перенаправившая часть стока Конго на восток, в межрифтовую тектоническую впадину, где образовалось огромное озеро Виктория - последний недостающий элемент будущей грандиозной гидросистемы Нила (см.: [Shahin, 1985]). Могучий Пренил с его интенсивной наносной деятельностью внес важнейший вклад в формирование ландшафта исторического Египта: так, отложенные им поверх плотных влагонепроницаемых глин Палеонила песчаные толщи послужили главным вместилищем грунтовых воА Аолины (обнажения тех же песков промышленно разрабатываются Аля целей городского строительства по всей стране), а возвышающиеся наА низовыми пойменными землями алмювиальные песчаные холмы пренильского происхождения - так называемые «черепашьи спины»- сыграли цементирующую роль надежных постоянных пристанищ (кое-где разросшихся в города: Буто, Мендес и Ар.) при заселении египтянами избыточно увлажненной и заболоченной АО- и раннединастической Аельты (см.: [Прусаков, 2009]).

Стабильно-полноводный Пренил резко «иссяк» около 400 тыс. Ает назад, что отмечено специалистами как переход к фазе Неонила - реки-трансформера с переменным объемом стока, которая то утрачивала, то восстанавливала, то приобретала новые связи с «африканскими источниками» в зависимости от континентальных и глобальных тектонических, климатических и Аругих природных сАвигов или

\footnotetext{
${ }^{6}$ К причинам неустойчивости плейстоценовой «протореки», помимо «ариАного, с фмуктуациями» египетского климата, Р. СаиА относиц «высокую сейсмическую активность в Египте и Красноморье», сопровожАавшуюся прерываниями «прежнего Аоступа нильской АОАины к южному водоснабжению» [Said, 1976].

7 Западная ветвь Восточно-Африканского разлома (рифтовой долины), содержащая озера Танганьика, Киву, ЭАуарА, Альберт и Ар. Восточную ветвь с озером Рудольф (Туркана) называют Кенийским рифтом (он же Грегори). В их развилке межит озеро Виктория.
} 
катаклизмов. Среди ее Аревних формообразований различают наиболее водоносный альфа-Неонил, вбиравший в себя суммарный сток Эфиопского нагорья, Нубийского массива и египетских восточных вади ${ }^{8}$, и подпитывавшийся мишь из Эфиопии значительно обмелевший, Ааже сезонный (возможно, пересыхавший или превращавшийся в цепочку маленьких озер зимой наподобие нынешней Атбары) бетаи гамма-Неониц вюрмской медниковой эпохи с ее аридизацией африканских климатов [Said, 1993]. По имеющимся оценкам, около 30-15 тыс. мет назад или на исходе вюрма Неониц, откатившись к востоку от террас Пренила и своих собственных ${ }^{9}$, стал прокладывать в Египте «финальное» русло одной из величайших рек земного шара, которая, однако, «сегодня» (в масштабе геологического времени это весь исторический периол) представляет собой не более чем «скромную наследнии могучих потоков, некогда господствовавщих в нильской долине», никогАа не Аостигавшую их максимального размаха [Said, 1976; 1981].

Эволюция нильского бассейна (см.: [Selley, 1997]) от разрозненных водосборов к конфигурации и режиму его сегодняшней сложносоставной гиАросети, неотделимой и полностью зависимой от постоянных «великих» озер Восточно-Африканского разлома (Виктория, Альберт и Ар.) и Эфиопии (Тана), включала спорадическое образование на различных русловых участках Реки временных водоемов, обусловленное особенными сочетаниями, как правило, климатического и иных параллельно благоприятствовавших этому «случайных» естественных факторов. Хронологически ближайшими к нам примерами разной степени гипотетичности явцяются: «мегаозеро Бемый Ним» Алиной АО 650 км и шириной до 80 км, возникшее на чрезвычайно пологой равнине межАу устьем Собата и Хартумом, по одной из версий, $109 \pm 8$ тыс. мет назаА и просушествовавшее несколько (Ао Аесяти) тысяч мет [Barrows et al., 2014; Williams, 2009; Williams et al., 2003]; «озеро Махадма», разливавшееся 24-18 тыс. мет назаА на всю ширину Аолины в запруженной песчаными эоловыми наносами «фиванской излучине» верхнеегипетского Нила выше Наг-Хаммади [Vermeersch, van Neer, 2015; Vermeersch, van Neer, Gullentops, 2006]; «выход из берегов» на 20-40 км Белого Нила в Судане вследствие резкого увеличения общенильского стока («Wild Nile» [Butzer, 1980]) на рубеже плейстоцена и голоцена ${ }^{10}$, с Аальнейшим сохранением на этом речном отрезке цепи озер и болот приблизительно до VII тыс. до н. э. [Barrows et al., 2014; Said, 1993; Williams, 2009]. По моей гипотезе, еще одно «море» на Ниле, размерами и глубинами сопоставимое с «экваториальным» озером А^ьберт на границе Уганды и Аемократической Республики Конго, могло образоваться в Египте межАу Асиутом и Фаюмом в VII-IV тыс. Ао н. э. в ходе фландрской трансгрессии Мирового океана и очередного повышения полноводности Реки в условиях потепления раннего и среднего голоцена с кульминацией (около 5500 некалибр. А. н. $\approx 4344$ г. АО н. э. [КАименко, 1997]) влажного атлантического термического оптимума [Прусаков, 2018a]. Именно такого

\footnotetext{
${ }^{8}$ С ним соотносятся найденные П. Бовье- Аапьером в 1920 г. близ Каира ашельские орудия, впервые археологически удостоверившие присутствие человека на Реке уже в нижнем палеолите [Bovier-Lapierre, 1925; Sandford, Arkell, 1929].

9 Геологи распознавали наА современной нильской поймой 30-, 23-25-, 8- и 6-метровую террасы разных «генераций» Неонима [Said, 1993].

${ }^{10}$ Началу голоцена ставится в соответствие ратифицированная МежАународным союзом геологических наук дата $11700 \pm 99$ калибр. ^. н. [Walker et al., 2009].
} 
рода гидрологический феномен в масштабах страны мог создать помеху территориальному контакту и слиянию Верхнего и Нижнего Египта в неолите ${ }^{11}$, когда Верхний Египет и Нижняя Нубия (традиции Нагада и Группа A, IV тыс. до н. э.), наоборот, развивали все более тесные этнические, культурные, торговые и прочие цивилизационные взаимоотношения, рассмотренные в первой части настоящей статьи [Прусаков, 2019а].

Воспрепятствовав в обозначенный период (Нагада I) аналогичному «интеграционному» сближению севера и юга Египта, среднеегипетское «голоценовое море» своим исчезновением из нильской Аолины во второй половине IV тыс. Ао н. э. (НагаАа II-III) Аолжно было с той же вероятностью способствовать их первичному геополитическому объединению на этапе прото- и раннединастического (архаического) государства фараонов. При этом нет никаких сомнений в том, что это объединение и синхронное ему резкое отпадение Нижней Нубии, с превращением ее в неприятельское зарубежье и разрушением складывавшегося веками «симбиоза» верхнеегиптян и «эфиопов» в Авустороннем приграничье 1-го («Сиенского») порога Нила ${ }^{12}$, были эпизодами общего исторического процесса генезиса Аревнеегипетской цивилизации. Стремительный разрыв с Нубией сопровожАался, по-виАимому, существенным сокращением населения северной оконечности страны межАу Ааккой и Асуаном (см.: [Nordström, 2004]), социально-экономическим и политическим крахом Группы А и, в итоге, ее полным отмиранием во времена I-II династий ${ }^{13}$. «Были предприняты бесплодные исследования в поисках чего-то вроде климатических изменений, которые могли вызвать столь внезапный колцапс в тот самый момент, когда Группа А находилась на вершине своего развития» [Midant-Reynes, 2000]. Не найАя объяснений в природе, «еАинственной причиной» случившегося специалисты объявили Египет, изначально АОминировавший в многогранных доисторических связях с Нубией, а при переходе к государству и перенаправлении используемых материальных ресурсов под контроль новоявленной Аинастической власти решивший покончить с посреАниками в торгов е на южных путях, реорганизовав ее так, «чтобы в ней не было места коренному нижненубийскому населению» [Török, 2009]. Отныне за зАешними товаропотоками, предположительно, наАзирали египетские «царские войска» ${ }^{14}$, и именно тогАа у «Аюдей культуры НагаАа» могло возникнуть упроченное особым тревожным топонимом представление о «Та-сети»— «Земле (нубийского) ${ }^{15}$ мука» за катарактом, откуда

\footnotetext{
${ }^{11}$ Египетский неолит Аатируется VI — серединой IV тыс. Ао н. э. (см.: [Прусаков, 2009]).

12 «Согласно исследованиям А-ра Элмиота Смита, Ааже раса в обоих регионах одинакова. Аругими словами, в Аревнейший период... Египет и Нижняя Нубия, похоже, образовывали культурно и расово одну страну» [Reisner, 1910]. Грэфтон ЭАлиот Смит (1871-1937) - австрало-британский анатом и антрополог (см., например: [Smith, 1916; 1923]). Ср.: Аробышевский С. В. О расах Аревнего Египта и Нубии. Антропогенез.py. URL: http://antropogenez.ru/zveno-single/302/ (Аата обращения 27.09.2019).

13 Аишь спустя более чем полтысячелетия, при ранней VI Аинастии, на смену Группе А к югу от 1-го порога пришли «чифдомы» земледельческо-скотоводческой культуры Группы С, известные из староегипетских источников как «негры» (или «кушиты») irT.t, wAwAt и Аp. [Reisner, 1910; Bietak, 1968; Török, 2009; Urk. I, 101].

14 «Не этот Аи новый поворот событий нашел отражение в наскальных рисунках Гебель Шейх Сулейман?» [Midant-Reynes, 2000].

${ }^{15}$ Cм.: [Vinogradov, 2000].
} 
происходила Группа А — как о стране враждебных и опасных иноплеменников [Valbelle, 1990].

Вероятно, уже при I Аинастии на возвышенности «восточного острова» ${ }^{16}$ Элефантины египтяне построили из сырцового кирпича крепость площаАью око о $50 \times 50$ м, с Авойными, усиленными поперечными перемычками стенами как минимум трехметровой высоты, с угловыми и, возможно, промежуточными башенками, которая господствовала наА «главным рукавом» Нила и противоположным низменным берегом, где сегодня межит город Асуан [Kaiser et al., 1993]. Закладка крепости, ознаменовавшая «решающий перелом в истории местного поселения», однако, поначалу вряА $\Lambda и$ предусматривала непосредственно его защиту, поскольку жилища оставались и за пределами фортификационного сооружения, чьи «архитекторы», очевиАно, выбирали позицию повыгоднее, «мацо заботясь о том, что было зАесь раньше»; особенно «вопиюще» это проявилось в их небрежном отношении к старейшему на Элефантине, уходящему корнями в герзейский период святилищу «богини прохлаАной воды» Сатет, которое не только не попало внутрь возводившихся вплотную к нему крепостных стен,

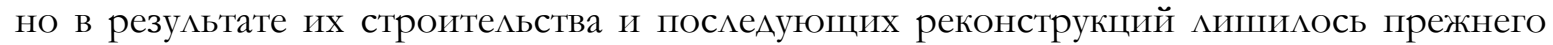
удобного входа и значительной части внешнего Авора [Seidlmayer, 1996]. Этот, несомненно, очень поспешно возАвигнутый форт, чужеродный «автономной эволюции местной общины» и, не исключено, укомплектованный гарнизоном из Нижнего Египта [Kaiser et al., 1988], «мог служить трамплином Аля набегов в Нубию, таких как карательная кампания, задокументированная на ярлыке Aха» ${ }^{17}$ [Wilkinson, 1999].

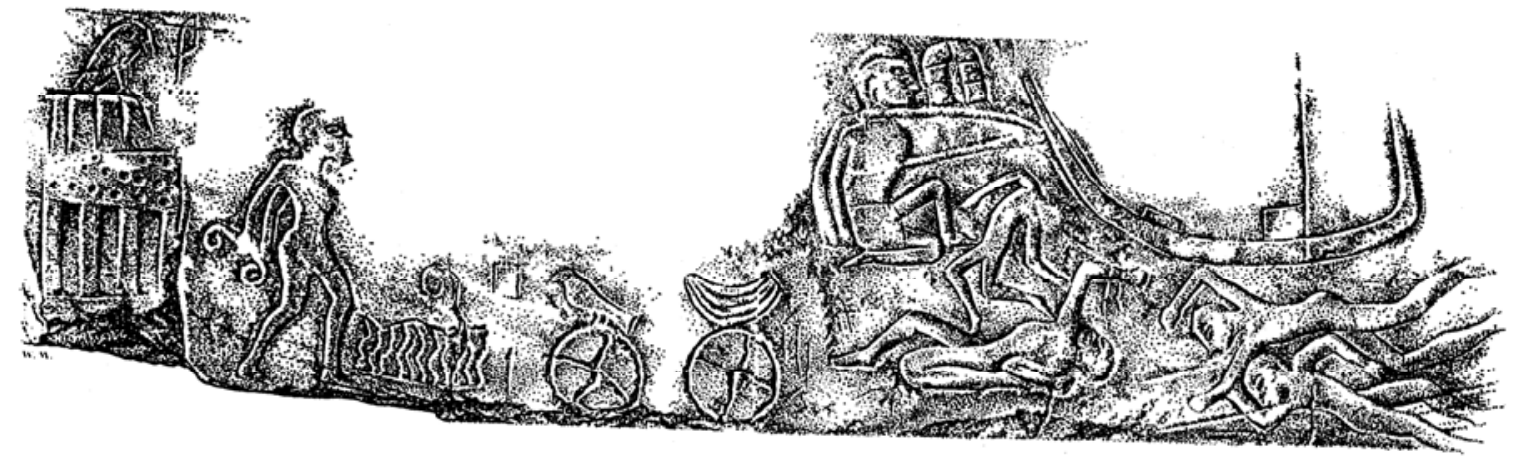

Илл. 1. Петроглифы Гебель Шейх Сулейман, Нижняя Нубия (по: [Arkell, 1975, fig. 24])

С Аругой стороны, вышеупомянутое падение на закате Группы А численности

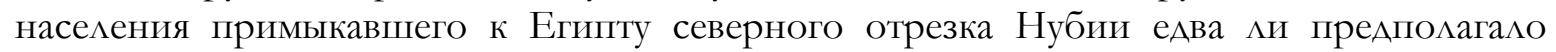
острую необходимость создания нацеленного на данный регион верхнеегипетского «укрепрайона»-плацдарма, если только, например, не увязывать оба явления с «аналогичными» опустошительными нижненубийскими кампаниями предшественников Хора Аха - царей «позднего Аодинастического периода / “0-й Аинастии”». О такого рода Аревнейших «рейлах», как о непреложных фактах, писали Т. Уилкинсон и другие египтологи, приводя в Аоказательство петроглифы песчаниковой скалы Гебель Шейх Сулейман на западном берегу Нила близ Вали Хальфа (илл. 1), якобы

16 См. Аалее в Части III данной статьи, которая будет опубликована в следующих номерах журнала «Вестник Института востоковедения РАН».

${ }^{17}$ См. илм. 4 в: [Прусаков, 2019а]. 
свидетельствующие о попытках покорения страны Та-сети египтянами в протодинастические, а то и более незапамятные времена [Murnane, 1987; Wilkinson,

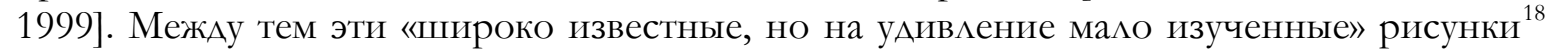
ряд исследователей приписывац преемнику основателя I Аинастии Аха Хору Ажеру [Arkell, 1950; Needler, 1967; Somaglino, Tallet, 2014; 2015] ${ }^{19}$; по оригинацьной версии Б. Уильямса, запечатленные в рассмотренных петроглифах ратные события, увенчавшиеся разгромом, избиением и пленением некоего противника, хотя и произошли в периол Нагада III (a-b), но относились не к 0-й Аинастии верхнеегипетских царей, а к правившей «несколькими поколениями» Ао нее «Кустульской династии Группы A» [Williams, 1980; 1987], которая увековечила таким образом свою воинскую победу, одержанную «гАе-то на юге, вероятнее всего в ареале культуры преА-Кермы» (3500-2500 гг. Ао н. э. [Bonnet, 1992]) ${ }^{20}$, т. е. в Верхней Нубии у 3-го нильского порога [Bonnet, 1997; Honegger, 2004]. Кстати, подобно нубийскому приграничью 1-го порога на исторический момент возникновения египетского протогосударства и упалка Группы А, окрестности Кермы ранее, в первой половине IV тыс. Ао н. э., также на время почти обезлюдели [Honegger, Williams, 2015], и весьма ^юбопытно, что палеогеографы сопоставляли данный археологический эпизод не только с развивавшейся по завершении атлантического оптимума аридизацией Сахары, но и с регрессией танзанийско-кенийского кратерного озера Чала неподалеку от вулкана Килиманджаро, в прелелах Восточно-Африканской рифтовой Аолины, заключающей в себе «великие озера» верховий Белого Нима [Verschuren et al., 2009; Williams, 2019]. Если эта регрессия, наряду с понижением уровней озера Альберт межАу 5500 и 4200 некалибр. ^. н. [Williams et al., 2006] и озер Эфиопского нагорья 60004000 некалибр. ^. н. [Gasse, Street, 1978; Grove, Street, Goudie, 1975], служит индикатором синхронной убыли нильского стока (см.: [Adamson et al., 1980]), то не продвигаются Аи здесь «бесплодные исследования» [Midant-Reynes, 2000] в установ ении природно-кАиматического фактора, который оказац вАияние на процесс Аревнеегипетского государствогенеза?

Известно (ср.: [Grove, Warren, 1968]), что в IV тыс. Ао н. э. обильная водоносность дельта-Неонила [Said, 1993], обнаруживавшая тенденцию к уменьшению на протяжении всего среднего голоцена (ср.: [Butzer, Hansen, 1968]), резко устремилась вниз, коррелируя с прогрессировавшими в Северной и Восточной Африке аридизацией, сокращением зоны и количества метних муссонных Аождей и усыханием «тысяч» [Woodward et al., 2015] вливавшихся в Реку водотоков ваАи (см. также: [Dufton, Branton, 2010]). «В период позАнего неолита и додинастики (около 3350 г. Ао н. э.) внезапное падение уровня Нила обнажило большие площади речного русла (курсив мой. — А. П.)... Формирование современного облика заливной поймы началось примерно в эпоху Группы А и Раннего царства» ${ }^{21}$ [de Heinzelin, 1968; cp.: Fairbridge, 1962]. При этом, по выкладкам археологов, обследовавших «асуанский резервуар» перед его затоплением

\footnotetext{
18 В 1963 г. перевезены в Национальный музей Судана в Хартуме [Hinkel, 1965].

19 Поначалу их датировали даже XI династией [Sayce, 1910].

${ }^{20}$ См.: Williams B., Kleinitz C., Reshetnikova N., Unhammer O. The Gebel Sheikh Suleiman Monument. URL: https://www.academia.edu/34223600/The_Gebel_Sheikh_Suleiman_Monument (Аата обращения 06.10.2019). 21 «Ранним царством» иногда называют архаический (раннединастический) этап истории фараоновского Египта, предшествовавший Аревнему (Старому) царству.
} 
озером Насер, «культурное пространство нильской Нубии» к северу от 2-го порога с проникновением в Египет «по меньшей мере до 1-го катаракта, а возможно, и за Ком Омббо» получило развитие Ао указанного «ГАубоокого понижения» («неолитического спада») Гцавного Нила [Wendorf, 1968]. По оценкам австралийского геолога и палеоклиматолога Р. Фэрбриджа, в начале IV тыс. Ао н. э. годовой объем нильского стока достигаА 120-150 км ${ }^{3}$ т. е. превосходил современный (составАяющий в среднем 85 км$\left.^{3}\right)$ на 41-76\%, а разливы в Нубии могли быть выше их исторической нормы на 15 м; предположительно, Ааже на излете «неолитического спада» около 3200 г. АО н. э. ${ }^{22}$ сток Нила был объемнее сегодняшнего на 20 \% [Fairbridge, 1976], что, не исключено, нашло отражение в Аревнеегипетской метописи Палермского камня [O’Mara, 1979; Schäfer, 1902], зафиксировавшей «аномально» высокий, превышавший минимум этого списка на $\sim 4$ м, разлив в 30-й гоА ${ }^{23}$ царствования царя I Аинастии Хора «Аена» [Прусаков, 1996] (чье сложное Аля понимания имя египтологи ${ }^{24}$ АОАго интерпретировали как Wdj-mw — «Податель Воды», см.: [Большаков, 2015]). С такого рода Аанными идеально согласуются сосредоточенные вдоль Реки в Нижней Нубии (см.: [Almagro Basch, Almagro Gorbea, 1968; Engelmayer, 1965]) Аоисторические петроглифы прежде всего «прямоугольных» [Winkler, 1938] — «морских» [Прусаков, 2015] АоАок, которые в «период торгов и» межАу культурой НагаАа и Группой А, вероятно, обеспечивали перевозку Аюдей и грузов на участке полноводнейшего АельтаНеонила «от Верхнего Египта Ао порогов Батн эль-Хагара» [Midant-Reynes, 2000].

Аовольно разнообразная в целом петроглифика этого района (точнее, того, что от него осталось после возведения Высотной Асуанской плотины и Аостижения водохранилищем Насер эксплуатационного уровня) распространилась здесь в эпипалеолите/неолите и резко сошла на нет по окончании Аодинастики [Storemyr, 2009; cp.: Gatto et al., 2009]. Простейшие «геометрические» узоры, представляющие собой прямые и извилистые Аинии, окружности, сетки и т. п., Аатируются специалистами начиная с IX-VII тыс. АО н. э., причем, «несмотря на множество подходящих Аля их нанесения прибрежных скальных обнажений», располагаются они на некотором удалении от Нила. «Возможно, имелись природные причины наблюдаемого отсутствия следов раннего наскального искусства непосредственно у реки, если только те не были скрыты песчаными Аюнами или разрушены ${ }^{25}$ » [Storemyr, 2009]. ОАна из них гипотетически могла заключаться в неразвитости алмювиального почвенного покрова, что Ао VI-V тыс. Ао н. э. слерживало массовое заселение нильской (в первую очередь египетской) поймы, еще не пригодной Аля земледелия [Прусаков, 2009; cp.: Kuper, Kröpelin, 2006]. Вместе с тем данную археологическую ситуацию заманчиво связать с вопросом об урезах воды ГАавного Нила в среднем голоцене, несомненно, пролегавших несколько выше береговых границ исторического времени, протодинастический пролог которого (НагаАа III), по-виАимому, совпац с завершением «неолитического спада» Реки.

Из более позАних петроглифов рассматриваемого комплекса, запечатлевших АОАки, Аюдей и животных, хронологически ближайшими к «геометрическим» считаются

\footnotetext{
${ }^{22}$ Или 4500 некалибр. ^. н. $\approx 3221$ г. Ао н. э. [Williams et al., 2010].

${ }^{23}$ Cp.: [Helck, 1966].

${ }^{24}$ См., например: [Emery, 1961; Gardiner, 1961].

25 В результате активной древней камнедобычи (см.: [Bloxam, Heldal, Storemyr, 2007]).
} 
рисунки жирафов, относящиеся к периоду Нагада I [Huyge, 1998] и даже, «вполне вероятно», к началу IV тыс. Ао н. э., а также крокодилов, «весьма возможно», предшествовавшие Аодинастике и частью параллельные «эпипалеолитическим художественным мотивам» ( 9000/7000-5000 гг. Ао н. э. $)^{26}$. «Крокодильи» петроглифы

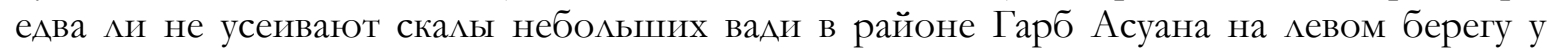
подножия 1-го порога; особенно показательно панно Р223-4, так называемый «пляж крокодилов» в водосборе Вади Рамла в полутора-двух километрах от Нила, где рептилии высечены в естественном углублении рядом с широкой трещиной в каменном основании, словно они только что «вылезли из реки» [Storemyr, 2009] (uлл. 2). Первобытные наскальные рисунки влаголюбивых животных в ныне засушливых нильских окрестностях, как и в целом в Caxape [Le Quellec, 2013; Muzzolini, 1995], «наглядно» подтвержАают фундаментальное палеогеографическое положение о гумидности североафриканских климатов в раннем и среднем голоцене (см.: [КАименко, 2009; Butzer, 1958; 1959b]), при этом если жираф напоминает о послеледниковых саванновых ^андшафтах на пространствах сегодняшних пустынь, то крокодил, очевидно, еще и о наличии у Аельта-Неонила в соответствующих местах притоков или иных водных придатков [Прусаков, 2019б].

Аля оАного такого места с

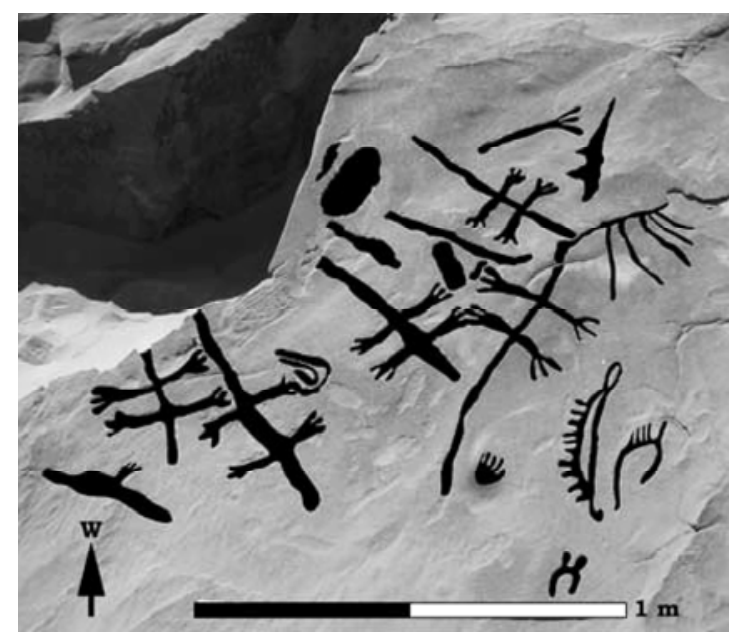

Илл. 2. «Пяяж крокодилов». Петроглифы в водосборе Вади Рамıа, Верхний Египет

(по: [Storemyr, 2009, fig. 16]) изображениями «толстотелых» крокодицов возле поселка Эль-Хош на западном берегу Реки в 30 км к югу от ЭАфу по компонентам целАюлозной органики (растительным волокнам), содержавшимся в патине петроглифов, была с помощью ускорительного масс-спектрометра установлена «верхняя» радиоуглеродная дата последних: $6690 \pm 270{ }^{14} \mathrm{C} \Lambda$. н., в календарном выражении terminus ante quem 5900/5800-5400/5300 гг. Ао н. э. [Huyge, 2005; Huyge et al., 2001]. Этому времени близка начавшаяся ориентировочно 6500 некалибр. ^. н. $\approx 5472$ г. Ао н. э. ${ }^{27}$ трансгрессия так называемого «Неолитического» Меридова озера в Фаюмском оазисе [Hassan, 1986], обусловленная «поступлением масс воды из Нила, принесших с собой группу моцАюсковой фауны, типичной Аля нильской Аолины» [Kozlowski, Ginter, 1993]. Подобные данные, указывающие на высочайшую полноводность ГАавного Нила на том этапе, могут служить аргументом в пользу как уже весьма значительной, если не максимацьной, развитости гипотетического «голоценового моря» в СреАнем Египте [Прусаков, 2018а; 2018б], так и экстремального уровня подпруженной им Реки вверх по

26 Cp.: Storemyr P. The Little-Known Archaeology of Gharb Aswan, Upper Egypt. URL: https://perstoremyr.net/2013/02/27/the-little-known-archaeology-of-gharb-aswan-upper-egypt/ (Аата обращения 21.10.2019).

${ }^{27}$ Или $6480 \pm 170{ }^{14}$ С м. н. $\approx 5583-5297$ гг. до н. э. (cp.: [Dagnan-Ginter et al., 1984; Wenke et al., 1983]). 
течению, с ее пропорциональным региональной геоморфологии растеканием за пределами современных береговых миний.

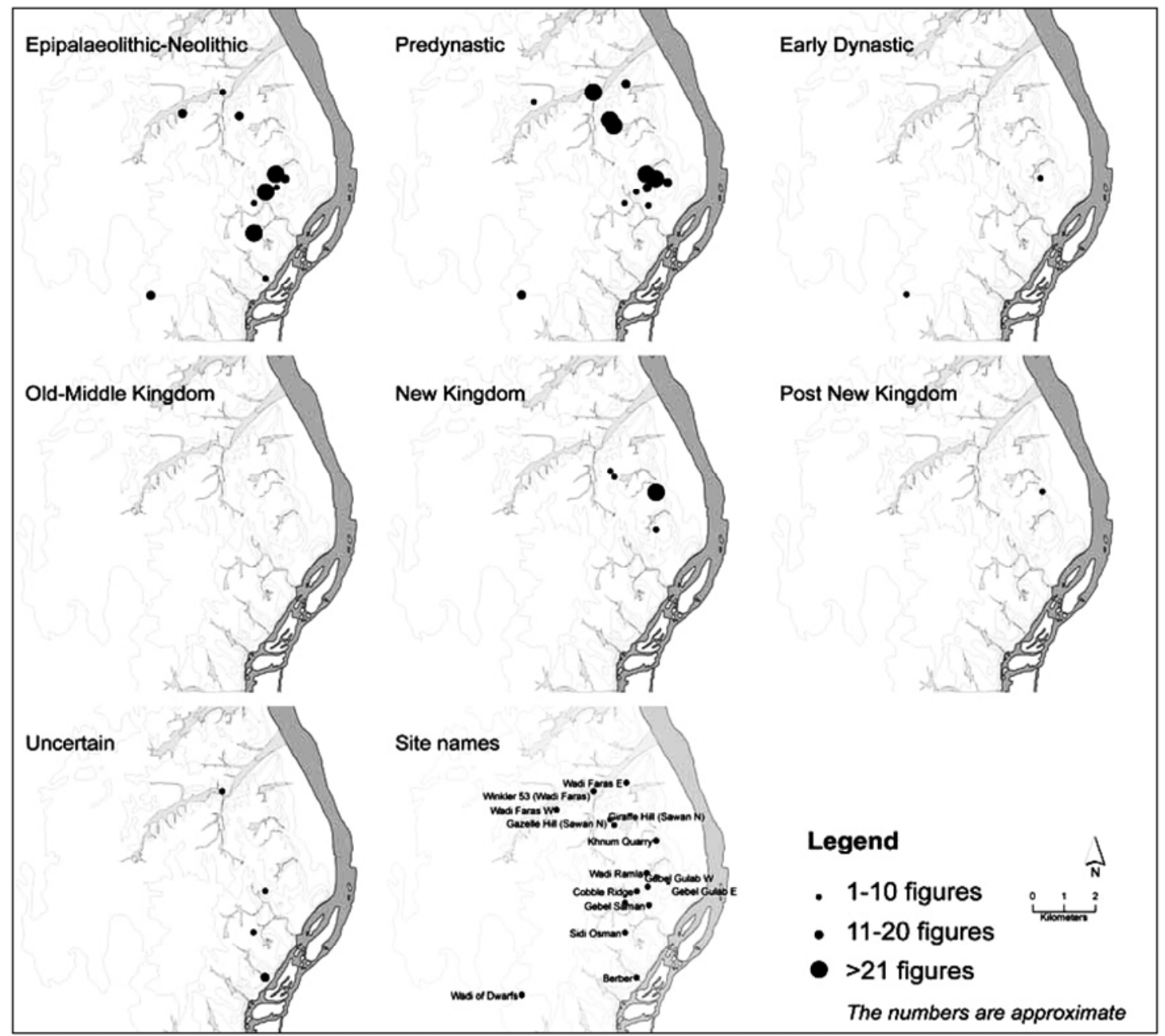

Илл. 3. Местоположения петроглифов Гарб Асуана (по: [Storemyr, 2009, fig. 21])

В этой связи привлекает внимание расположение Аревнейших петроглифов в доступном Аля полевого исследования районе Гарб Асуана (uлл. 3): совместив на общем плане имеющиеся археологические отметки их «кластеров» периода от эпипацеолита до архаики, мы увилим, что основные (фиксирующие наибольшие скопления рисунков) пунсоны образуют кривую, которая повторяет изгиб прилегающего отрезка нильского русла (uлл. 4). Аля сравнения, именно такую конфигурацию, наблюдаемую, например, в центральном сегменте озера Насер, очерчивают вершины заливов в затопленных Нилом окрестных вади (uлл. 5-б). Мысленно перенося эту гилрографическую картину на верхнеегипетский водосбор Нила в среднем голоцене, сошлюсь еще и на тот Ао сих пор не получивший единого научного толкования факт (см.: [Прусаков, 2015]), что доисторические наскальные рисунки в сухих вади южного Верхнего Египта по обеим сторонам Реки включают, как одни из важнейших, Аовольно многочисленные изображения крупных модок [Červiček, 1986; Winkler, 1938; 1939]. 


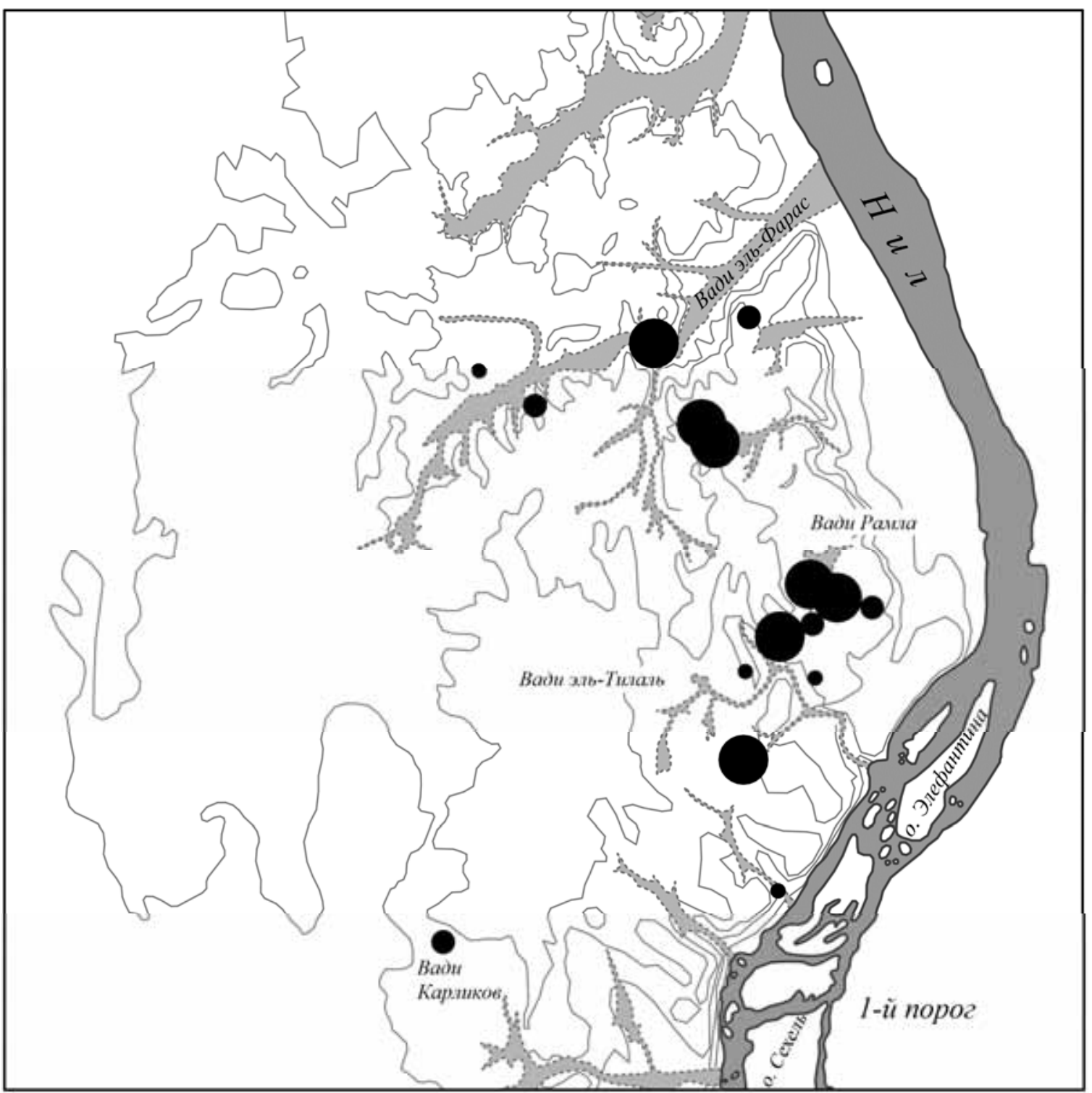

Илл. 4. Местоположения петроглифов Гарб Асуана до «неолитического спада» Нила (рuс. C. В. Ветохова по: [Storemyr, 2009, fig. 21])

Западноасуанскому петроглифическому очагу приналлежит известное местоположение, которому впервые изучивший и опубликовавший его немецкий этнолог Х. Винклер в своих экспедиционных Аневниках присвои порядковый номер 53. «Около 5 км к северу от Асуана, западный берег, короткое ваАи. В этом ваАи, приблизительно в 3,5 км западнее реки, скалистый остров. Жирафы, антилопы, газели, крокодилы, страусы; рогатый скот, собаки. Аюди, некоторые с перьями на голове. Аодки...» [Winkler, 1939]. Аанный художественно-археологический памятник «Ао определенной степени отражает весь мандшафт наскацьного искусства Гарб Асуана» [Storemyr, 2009]. "Short wadi” — это упоминавшееся в первой части настоящей статьи ВаАи эль-Фарас [Прусаков, 2019а], прославившееся петроглифами многовесельных

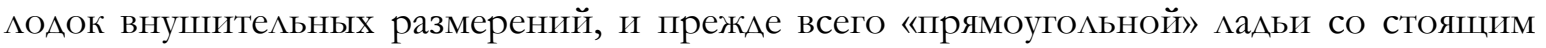


в ней протодинастическим (?) «царем в белой короне», Авойники которого в таких же головных уборах и с посохами в руках представлены несколькими сотнями метров южнее «на скалах, огораживающих песчаную равнину» у поселка Наг эль-Хамдулаб, величественно выступающими под опахалами рядом с аналогичными судами, один - в окружении целой флотилии ${ }^{28}$ [Hendrickx, Darnell, Gatto, 2012]. Похожие «вездесущие и часто большие изображения церемониальных мадей» [Darnell, 2015], с сопутствующими петроглифами жирафов и крокодилов, имеются также в ВаАи Рамла, в районе ВаАи эльТияаль и в Вади Карликов у подобия «маленького бассейна, который мог подАерживать растительность во вцажной фазе голоцена», являясь, наряду с ВаАи эль-Фарас, удобнейшим пунктом Аля проживания и промысла первобытного человека в гумидных кАиматических условиях [Storemyr, 2009].

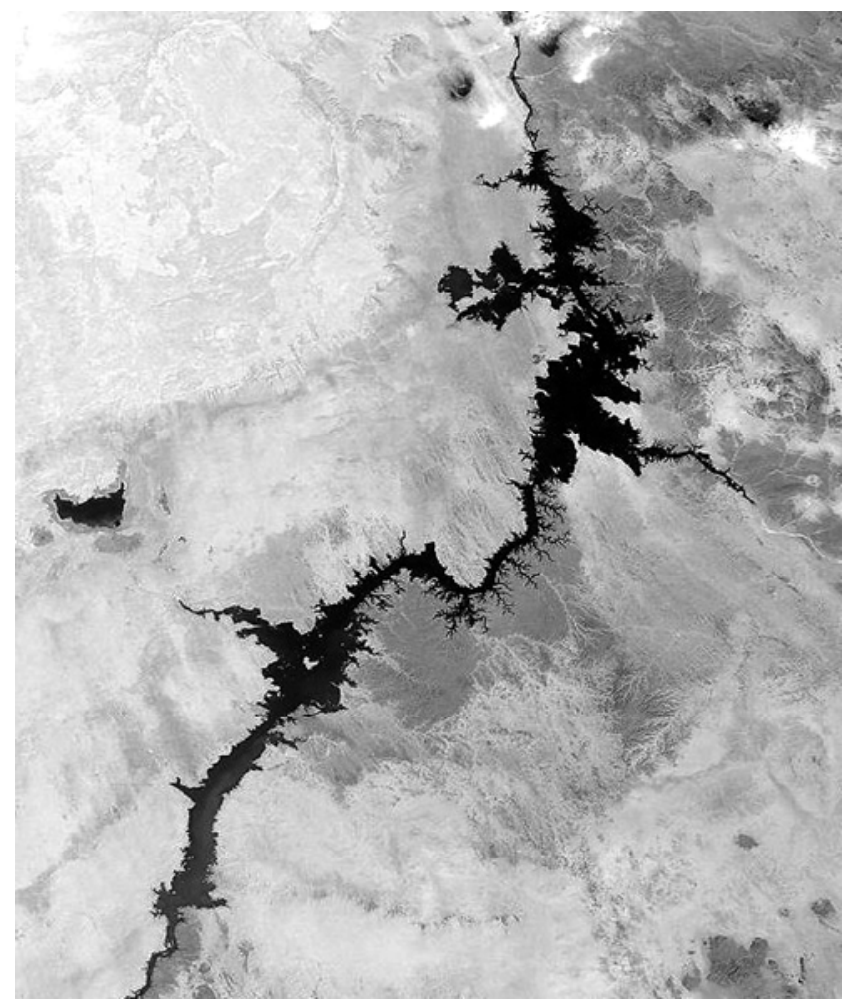

Илл. 5. Озеро Насер

(фото NASA:

http://looklex.com/e.o/slides/nasser_lake02.jpg)

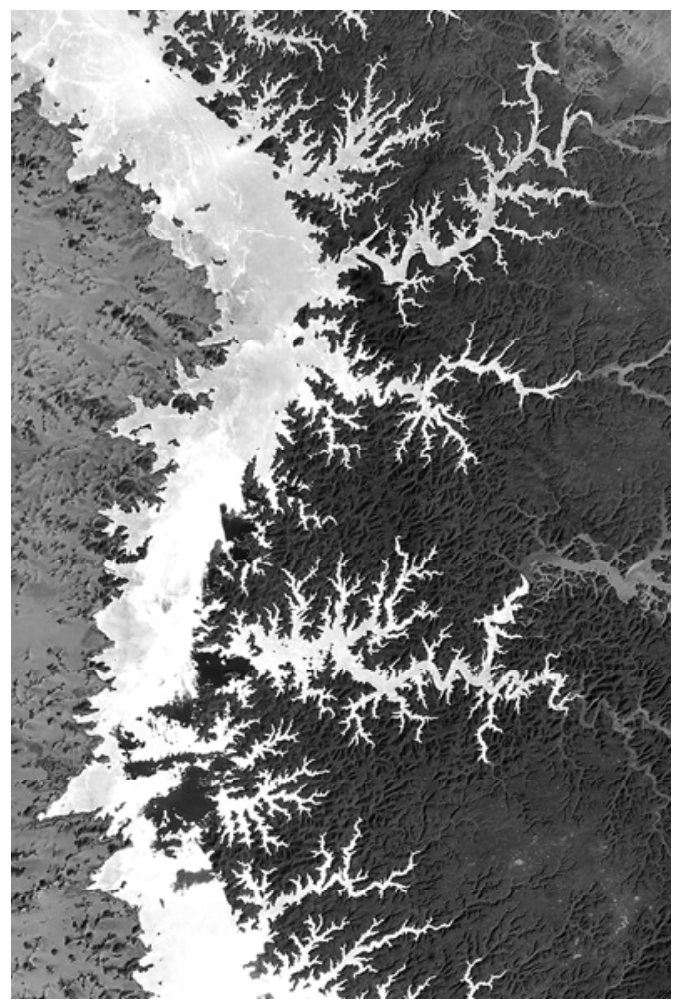

Илл. 6. Средняя часть озера Насер (фото NASA:

http://looklex.com/e.o/lake_nasser.htm)

«В итоге, Вади эль-Фарас выделяется как подходящее Аля Аюдей местообитание, благоприятствовавшее мелкому смешанному хозяйствованию в доисторические времена (охоте, собирательству, скотоводству и, возможно, рыболовству на реке)» [Storemyr, 2009], причем послеАний роА Аеятельности в таком контексте обязывает автора определиться в вопросе о связи рассматриваемого вади с нильским водотоком. Уточню, что отмеченный 53-м «сайтом» Х. Винклера "rocky island" - это отдельно стоящий вытянутый песчаниковый бугор, возвышающийся, по Аругим оценкам, на расстоянии

${ }^{28}$ См. имл. 8 и 9 в: [Прусаков, 2019а]. 
2,5 или 3 км от Нила в резком сужении Вади эль-Фарас, гАе оно образует «бутылочное горло» переА расширяюшейся Аальше к запаАу равниной [Červiček, 1986; Storemyr, 2009]. По мнению археологов (сетовавших, однако, на мощные наносы песка, которые, вероятно, никогАа не позволят Аокопаться до зАешнего культурного слоя), местность была весьма удобна Аля загона дичи и представляла собой идеальное охотничье угодье, с чем согласуется вышеперечисленная фауна ближних петроглифов. ОтАельного внимания заслуживает ее полуводный компонент, например, «большой крокодим» и «Ава Алинных крокодила», чьи изображения покрыты толстым слоем черной патины, что, скорее всего, свидетельствует об их значительной Аревности (не позднее периода НагаАа I, ср.: [Huyge, 2002]). Если принять, что крокодилы тогАа постоянно обитали в тех краях (см.: [Прусаков, 2019б]), то водоемом, необходимым им Аля круглогодичной жизни на таком удалении от Нила, гипотетически мог быть омывавший «скалистый остров» в ВаАи эль-Фарас речной залив, к берегам которого стекались рыбаки, тянулись на водопой привлекавшие охотников животные из соседней саванны, и приставали «церемониальные» мадьи с «царями» и без них на борту.

Это предположение не только не противоречит, но, на мой взгляА, Ааже Аобавляет правдоподобия догаАке археологов, что Вади эль-Фарас принадлежало к «участкам», гАе начинались или обрывались у Реки проторенные мюдьми еще в АОАинастическую эпоху торговые и прочие маршруты по нижненубийсковерхнеегипетскому мевобережному (галмабскому) педиплену (см.: [Butzer, Hansen, 1965] $)^{29}$, связанные через Нил с Восточной пустыней [Storemyr, 2007; Storemyr et al., 2013]. «Если наскальные рисунки Гарб Асуана были созАаны путниками, имевшими цели, отличные от местной охоты и камнеАобычи, то возникает вопрос: почему они располагаются в “конце” (или в “начале”) дорог? Можно ки это объяснить чем-то вроде паралмели с хорошо известной практикой ${ }^{30}$ установки простых вотивных стел (недекорированных камней) при входе в долину Нила или при выходе из нее? Аюди могАи собираться зАесь по столь же важным Аелам, что и в исторический периоА, а именно, Аля торговообменных операций. ИАи же они могли просто приметить этот район как становище, пригодное Аля рисования» [Storemyr, 2009]. Представив на месте засыпанного песком и выжженного солнцем ВаАи эль-Фарас нильский залив с функцией Аодочной гавани - не ответим Аи мы разом на большинство этих вопросов?

ИАею такого залива подкрепляет реконструированный норвежским геоархеологом П. Сторемюром Аля терминального плейстоцена («примерно 15-20 тыс. мет назаА $\left.{ }^{31}\right)$ «фьорА» в восточном Вади Абу Субейра с устьем в 12 км севернее Асуана и шириной около 1 км, вАававшийся в сушу на несколько (Ао 9-10) километров (uлl. 7); по Аополнительной версии реконструктора, устье ваАи, возможно, периодически блокировали песчаные Аюны, и тогАа «фьорА» превращался в «непостоянное озеро»,

\footnotetext{
29 «Под педипленом понимается поверхность выравнивания, образованная за счет разрушения возвышенностей путем физического выветривания их склонов» [Чумаков, 1967].

${ }^{30}$ Cp.: [Darnell, 2002; Jaritz, 1981].

31 С указанным временем все же ассоциируется аридизация последнего покровного оледенения; образование заливов в нильских вади с палеоклиматической точки зрения выглядело бы гораздо Аогичнее на влажно-полноводной стадии «Wild Nile», после «резкого возвращения» в Восточную Африку 1470013100 калибр. ^.н. ^етних мивневых муссонов (см: [Barker, Gasse, 2003; Butzer, 1998; Williams, 2009; Williams et al., 2006]).
} 
питавшееся дождевыми и грунтовыми водами ${ }^{32}$. Аатировку этого водоема ученым подсказали сохранившиеся на склонах ваАи - его предполагаемых берегах позАнепалеолитические натуралистичные петроглифы животных (в основном «Аикого рогатого скота», также рыб и Ар.) [Storemyr et al., 2008], имеющие аналоги еще в ряле точек южного Верхнего Египта [Huyge, 2008; Vermeersch, van Neer, Gullentops, 2006]. Независимо от Аанных оценок и суждений, внезапное прерывание Аревнейшей традиции наскацьного искусства Гарб Асуана на рубеже египетской Аодинастики и архаики (илл. 3) допустимо поставить в непосредственную связь с уходом нильских вод из вади и иных «бассейнов» береговой (ныне надпойменной) полосы в районе 1-го порога вследствие «неолитического спада» Реки во второй половине (ближе к концу) IV тыс. Ао н. э., резко обнажившего «большие площаАи» ее среднеголоценового рус $а$ [de Heinzelin, 1968].

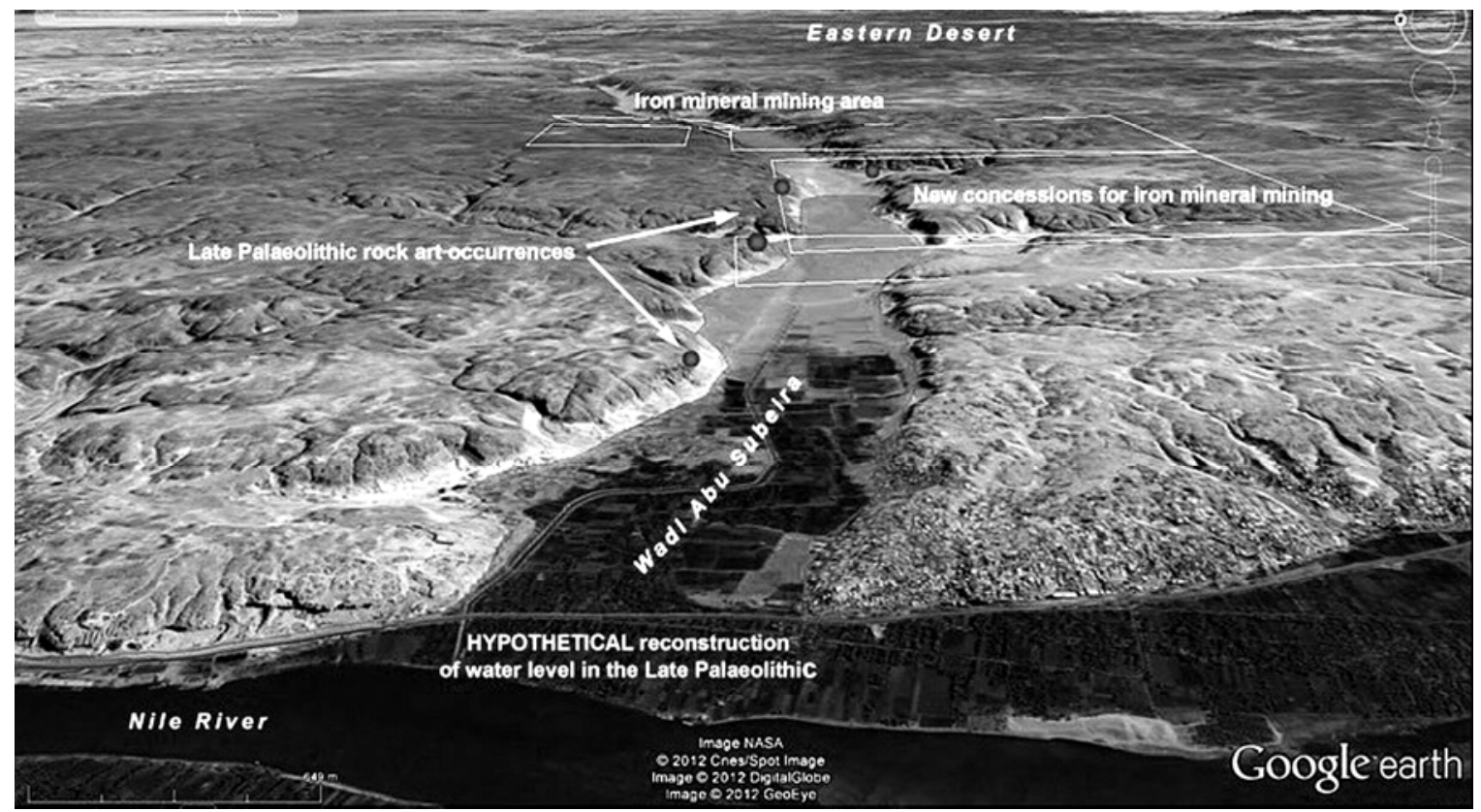

Илл. 7. Реконструкция позднепалеолитического «фьорда» в ВаАи Абу Субейра, Верхний Египет (по: https://per-storemyr.net/2012/05/01/the-palaeolithic-rock-art-in-wadi-abu-subeira-egyptlandscape-archaeology-threats-and-conservation/)

\section{Аитература / References}

Большаков А. О. К чтению и илеологии хоровых имен первых царей Египта. Большаков А. О. (реА.). Петербургкие египтологические чтения 2013-2014. Аоклады. СПб., 2015. С. 24-37 [Bolshakov A. O. On the Reading and Interpretation of the Horus Names of the First Kings of Egypt. Bolshakov A. O. (ed.). St. Petersburg Egyptological Readings 2013-2014. Papers of the Conference. St. Petersburg, 2015. Pp. 24-37 (in Russian)].

\footnotetext{
32 Storemyr P. The Palaeolithic Rock Art in Wadi Abu Subeira, Egypt: Landscape, Archaeology, Threats and Conservation. URL: $\quad$ https://per-storemyr.net/2012/05/01/the-palaeolithic-rock-art-in-wadi-abu-subeira-egypt-landscapearchaeology-threats-and-conservation/ (Аата обращения 26.11.2019).
} 
Клименко В. В. Климат: непрочитанная глава истории. М., 2009 [Klimenko V. V. Climate: An Unread Chapter of the History. Moscow, 2009 (in Russian)].

Клименко В. В. О главных климатических ритмах голоцена. Аоклады Академии наук. 1997. 357. C. 399-402 [Klimenko V. V. Principal Climatic Rhythms of the Holocene. Doklady Akademii nauk (Transactions of the Russian Academy of Sciences). 1997. 357. Pp. 399-402 (in Russian)].

Маловицкий Я. П., Чумаков И. С., Шимкус К. М., Есина А. А., Москаленко В. Н. Земная кора и история развития Средиземного моря. М., 1982 [Malovitsky Ya. P., Chumakov I. S., Shimkus K. M., Esina L. A., Moskalenko V. N. The Earth Crust and the History of the Development of the Mediterranean Sea. Moscow, 1982 (in Russian)].

Монин А. С., Шишков Ю. А. История климата. А., 1979 [Monin А. S., Shishkov Yu. A. The History of Climate. Leningrad, 1979 (in Russian)].

Прусаков А. Б. «Голоценовое море» в Среднем Египте: к независимым обоснованиям гипотезы. Вестник Института востоковедения РАН. 2018(б). № 6. С. 72-85 [Proussakov D. B. A "Holocene Sea" in Middle Egypt: Independent Validations of the Hypothesis. Vestnik Instituta vostokovedenija RAN. 2018(b). 6. Pp. 72-85 (in Russian)].

Прусаков А. Б. «Звериный стиль» Ао фараонов: египетская Аодинастическая наскальная и ремесленная изобразительность как палеогеографический источник (возвращение к проблеме). Ориенталистика. 2019(б). № 2 (3). C. 493-538 [Proussakov D. B. “Animal Style” Before the Pharaohs: Egyptian Predynastic Rock-Art and Handicraft Representationism as a Palaeogeographical Source (Return to the Problem). Orientalistica. 2019(b). 2 (3). Pp. 493-538 (in Russian)].

Прусаков А. Б. Гипотеза о «Земле изАияния Реки»: к предыстории 1-го порога в контексте гилрологии среднеголоценового Нила. Часть I. Вестник Института востоковедения РАН. 2019(a). № 3. C. 12-31 [Proussakov D. B. The Hypothesis of the "Land of Outpouring of the River": On the Prehistory of the First Cataract in the Context of Hydrology of the MidHolocene Nile. Part I. Vestnik Instituta vostokovedenija RAN. 2019(a). 3. Pp. 12-31 (in Russian)].

Прусаков А. Б. Аодинастическии Египет: лодка у истоков иивилизачии. М., 2015. [Proussakov D. B. Predynastic Egypt: The Boat at the Origins of Civilization. Moscow, 2015 (in Russian)].

Прусаков А. Б. Аревний Египет: почва чивилизачии (этюод о неолитической револтоии). М., 2009 [Proussakov D. B. Ancient Egypt: Soil of the Civilization (an Essay on the Neolithic Revolution). Moscow, 2009 (in Russian)].

Прусаков А. Б. Об одной «фикции» Палермского камня. Вестник древней истории. 1996. № 3. C. 73-76 [Proussakov D. B. On Some "Fiction" of the Palermo Stone. Vestnik drevnei istorii. 1996. 3. Pp. 73-76 (in Russian)].

Прусаков А. Б. Озера на Аоисторическом Ниле: «гидрологические» перспективы египетской археологии. Вестник Института востоковедения РАН. 2018(a). № 1. . [Proussakov D. B. Lakes on the Prehistoric River Nile: "Hydrological" Outlook for Egyptian Archaeology. Vestnik Instituta vostokovedenija RAN. 2018(a). 1. Pp. 70-80 (in Russian)].

Чумаков И. С. Плиоченовъге и плейсточеновые отложения долинь Нила в Нубии и Верхнем Ezunme. M., 1967 [Chumakov I. S. Pliocene and Pleistocene Deposits of the Nile Valley in Nubia and Upper Egypt. Moscow, 1967 (in Russian)].

Adamson D. A., Gasse F., Street F. A., Williams M. A. J. Late Quaternary History of the Nile. Nature. 1980. 288. Pp. 50-55.

Almagro Basch M., Almagro Gorbea M. Estudios de arte rupestre nubio. I. Yacimientos situados en la orilla oriental del Nilo, entre Nag Kolorodna y Kars Ibrim (Nubia egipcia). Madrid, 1968.

Arkell A. J. The Prehistory of the Nile Valley. Leiden, 1975.

Arkell A. J. Varia Sudanica. Journal of Egyptian Archaeology. 1950. 36. Pp. 24-40.

Arldt T. Zur Paläogeographie des Nillandes in Kreide und Tertiär. Geologische Rundschau. 1918. 9. S. 4756, 104-124. 
Barker P., Gasse F. New Evidence for a Reduced Water Balance in East Africa During the Last Glacial Maximum: Implication for Model-Data Comparison. Quaternary Science Reviews. 2003. 22. Pp. 823-837.

Barrows T. T., Williams M. A. J., Mills S. C., Duller G. A. T., Fifield L. Keith, Haberlah D., Tims S. G., Williams F. M. A White Nile Megalake During the Last Interglacial Period. Geology. 2014. 42. Pp. 163-166.

Bietak M. Studien zur Chronologie der nubischen C-Gruppe. Ein Beitrag zur Frühgeschichte Unternubiens zwischen 2200 und 1550 vor Chr. Wien, 1968.

Blanckenhorn M. L. P. Die Geschichte des Nil-Stroms in der Tertiär- und Quartärperiode, sowie des paläolithischen Menschen in Ägypten. Zeitschrift der Gesellschaft für Erdkunde zu Berlin. 1902. 37. S. 694-722, 753-762.

Bloxam E., Heldal T., Storemyr P. (eds.). Characterisation of Complex Quarry Landscapes: An Example from the West Bank Quarries, Aswan. Trondheim, 2007.

Bonnet C. Excavations at the Nubian Royal Town of Kerma: 1975-91. Antiquity. 1992. 66. Pp. 611625.

Bonnet C. Le groupe A et le pré-Kerma. Wildung D. (ed.). Soudan, royaumes sur le Nil. Paris, 1997. Pp. 36-47.

Bovier-Lapierre P. Le paléolithique stratifié des environs du Caire. L'Anthropologie. 1925. 35. P. 37-46.

Butzer K. W. Contributions to the Pleistocene Geology of the Nile Valley. Erdkunde. 1959(a). 13. S. 4667.

Butzer K. W. Studien zum vor- und frühgeschichtlichen Landschaftswandel der Sahara. I. Die Ursachen des Landschaftswandels der Sahara und Levante seit dem klassischen Altertum. II. Das ökologische Problem der neolithischen Felsbilder der östlichen Sahara. Wiesbaden, 1958.

Butzer K. W. Studien zum vor- und frühgeschichtlichen Landschaftswandel der Sahara. III. Die Naturlandschaft Ägyptens während der Vorgeschichte und der Dynastischen Zeit. Wiesbaden, 1959(b).

Butzer K. W. Late Quaternary Problems of the Egyptian Nile: Stratigraphy, Environments, Prehistory. Paléorient. 1998. 23. Pp. 151-173.

Butzer K. W. Pleistocene History of the Nile Valley in Egypt and Lower Nubia. Williams M. A. J., Faure H. (eds.). The Sahara and the Nile: Quaternary Environments and Prehistoric Occupation in Northern Africa. Rotterdam, 1980. Pp. 253-280.

Butzer K. W., Hansen C. L. Desert and River in Nubia: Geomorphology and Prehistoric Environments at the Aswan Reservoir. Madison, 1968.

Butzer K. W., Hansen C. L. On Pleistocene Evolution of the Nile Valley in Southern Egypt. Canadian Geographer. 1965. 9. Pp. 74-83.

Červiček P. Rock Pictures of Upper Egypt and Nubia. Napoli, 1986.

Chumakov I. S. Pliocene and Pleistocene Deposits of the Nile Valley in Nubia and Upper Egypt. Ryan W. B. F., Hsü K. J., Cita M. B., Dumitrica P., Lort J. M., Mayne W., Nesteroff W. D., Pautot G., Stradner H., Wezel F. C. (eds.). Initial Reports of the Deep Sea Drilling Project. Vol. 13. Washington, 1973. Pp. 1242-1243.

Dagnan-Ginter A., Ginter B., Kozlowski J. K., Pawlikowski M., Śliwa J. Excavations in the Region of Qasr el-Sagha, 1981. Contribution to the Neolithic Period, Middle Kingdom Settlement and Chronological Sequences in the Northern Fayum Desert. Mitteilungen des Deutschen archäologischen Instituts, Abteilung Kairo. 1984. 40. S. 33-102.

Darnell J. C. The Early Hieroglyphic Annotation in the Nag el-Hamdulab Rock Art Tableaux, and the Following of Horus in the Northwest Hinterland of Aswan. Archéo-Nil. 2015. 25. Pp. 19-43.

Darnell J. C. The Narrow Doors of the Desert. Ancient Egyptian Roads in the Theban Western Desert. David B., Wilson M. (eds.). Inscribed Landscapes. Marking and Making Place. Honolulu, 2002. Pp. 104-121. 
Dufton D., Branton T. Climate Change in Early Egypt. Egyptian Archaeology. The Bulletin of the Egypt Exploration Society. 2010. 36. Pp. 36-37.

Emery W. B. Archaic Egypt. Harmondsworth, 1961.

Engelmayer R. Die Felsgravierungen im Distrikt Sayala-Nubien. I. Die Schiffsdarstellungen. Wien, 1965.

Fairbridge R. W. Effects of Holocene Climatic Changes on Some Tropical Geomorphic Process. Quarternary Research. 1976. 6. Pp. 529-556.

Fairbridge R. W. New Radiocarbon Dates of Nile Sediments. Nature. 1962. 196. Pp. 108-110.

Garcia-Castellanos D., Estrada F., Jiménez-Munt I., Gorini C., Fernàndez M., Vergés J., Vicente R. de. Catastrophic Flood of the Mediterranean After the Messinian Salinity Crisis. Nature. 2009. 462. Pp. 778-781.

Gardiner A. H. Egypt of the Pharaohs. Oxford, 1961.

Gargani J., Rigollet C., Scarselli S. Isostatic Response and Geomorphological Evolution of the Nile Valley During the Messinian Salinity Crisis. Bulletin de la Société Géologique de France. 2010. 181. Pp. 19-26.

Gasse F., Street F. A. Late Quaternary Lake-Level Fluctuations and Environments of the Northern Rift Valley and Afar Region (Ethiopia and Djibouti). Palaeogeography, Palaeoclimatology, Palaeoecology. 1978. 24. Pp. 279-325.

Gatto M. C., Hendrickx S., Roma S., Zampetti D. Rock Art from West Bank Aswan and Wadi Abu Subeira. Archéo-Nil. 2009. 19. Pp. 151-168.

Grove A., Street F. A., Goudie A. Former Lake Levels and Climatic Change in the Rift Valley of Southern Ethiopia. Geographical Journal. 1975. 141. Pp. 177-202.

Grove A., Warren A. Quaternary Landforms and Climate on the South Side of the Sahara. Geographical Journal. 1968. 134. Pp. 194-208.

Hassan F. A. Holocene Lakes and Prehistoric Settlements of the Western Faiyum, Egypt. Journal of Archaeological Science. 1986. 13. Pp. 483-501.

Hayes W. C. Most Ancient Egypt. Chicago, 1965.

Heinzelin J. de. Geological History of the Nile Valley in Nubia. Wendorf F. A. (ed.). The Prehistory of Nubia. Vol. 1. Dallas, 1968. Pp. 19-55.

Helck W. Nilhöhe und Jubiläumsfest. Zeitschrift für ägyptische Sprache und Altertumskunde. 1966. 93. S. 7476.

Hendrickx S., Darnell J. C., Gatto M. C. The Earliest Representations of Royal Power in Egypt: The Rock Drawings of Nag el-Hamdulab (Aswan). Antiquity. 2012. 86. Pp. 1068-1083.

Hinkel F. Progress Report on the Dismantling and Removal of Endangered Monuments in Sudanese Nubia from August 1963 to August 1964. Kush. 1965. 13. Pp. 96-101.

Honegger M. The Pre-Kerma. A Cultural Group from Upper Nubia Prior to the Kerma Civilization. Sudan \& Nubia. The Sudan Archaeological Research Society Bulletin. 2004. 8. Pp. 38-46.

Honegger M., Williams M. A. J. Human Occupations and Environmental Changes in the Nile Valley During the Holocene: The Case of Kerma in Upper Nubia (Northern Sudan). Quaternary Science Reviews. 2015. 130. Pp. 141-154.

Hsü K. J. The Mediterranean Was a Desert: A Voyage of the "Glomar Challenger". Princeton, 1983.

Hsü K. J., Montadert L., Bernoulli D., Cita M. B., Erickson A., Garrison R. E., Kidd R. B., Mèlierés F., Müller C., Wright R. History of the Mediterranean Salinity Crisis. Nature. 1977. 267. Pp. 399_ 403.

Hsü K. J., Ryan W. B. F., Cita M. B. Late Miocene Desiccation of the Mediterranean. Nature. 1973. 242. Pp. 240-244.

Huyge D. 'Lascaux Along the Nile': The Palaeolithic Rock Art of Qurta (Upper Egypt). Bulletin des Séances de l'Académie Royale des Sciences d'Outre-Mer. 2008. 54. Pp. 281-296.

Huyge D. Cosmology, Ideology and Personal Religious Practice in Ancient Egyptian Rock Art. Friedman R. F. (ed.). Egypt and Nubia: Gifts of the Desert. London, 2002. Pp. 192-206. 
Huyge D. Possible Representations of Palaeolithic Fish-Traps in Upper Egyptian Rock Art. Rock Art Research. Journal of the Australian Rock. Art Research Association. 1998. 15. Pp. 3-11.

Huyge D. The Fish Hunters of El-Hosh: Rock Art Research and Archaeological Investigations in Upper Egypt (1998-2004). Bulletin des Séances de l'Académie Royale des Sciences d'Outre-Mer. 2005. 51. Pp. 231-249.

Huyge D., Watchman A., De Dapper M., Marchi E. Dating Egypt's Oldest 'Art': AMS 14C Age Determinations of Rock Varnishes Covering Petroglyphs at El-Hosh (Upper Egypt). Antiquity. 2001. 75. Pp. 68-72.

Jaritz H. Zum Heiligtum am Gebel Tingar. Mitteilungen des Deutschen archäologischen Instituts, Abteilung Kairo. 1981. 37. S. 241-246.

Kaiser W., Bommas M., Jaritz H., Krekeler A., Pilgrim C. von, Schultz M., Schmidt-Schultz T., Ziermann M. Stadt und Tempel von Elephantine: 19./20. Grabungsbericht. Mitteilungen des Deutschen archäologischen Instituts, Abteilung Kairo. 1993. 49. S. 133-187.

Kaiser W., Dreyer G., Jaritz H., Kretzeler A., Lindemann J., Pilgrim C. von, Seidlmayer St., Ziermann M. Stadt und Tempel von Elephantine: 15./16. Grabungsbericht. Mitteilungen des Deutschen archäologischen Instituts, Abteilung Kairo. 1988. 44. S. 135-182.

Kozlowski J. K., Ginter B. Holocene Changes in the Fayum: Lake Moeris and the Evolution of Climate in Northeastern Africa. Krzyzaniak L., Kobusiewicz M., Alexander J. A. (eds.). Environmental Change and Human Culture in the Nile Basin and Northern Africa Until the Second Millennium B. C. Poznan, 1993. Pp. 327-336.

Kuper R., Kröpelin S. Climate-Controlled Holocene Occupation in the Sahara: Motor of Africa's Evolution. Science. 2006. 313. Pp. 803-807.

Le Quellec J.-L. Périodisation et chronologie des images rupestres du Sahara central. Prébistoires Méditerranéennes. 2013. 4. Pp. 2-45.

Little O. H. Recent Geological Work in the Fayum and in the Adjoining Portion of the Nile Valley. Bulletin de l'Institut d'Égypte. 1936. 18. Pp. 201-240.

McKenzie J. A. From Desert to Deluge in the Mediterranean. Nature. 1999. 400. Pp. 613-614.

Midant-Reynes B. The Prehistory of Egypt. From the First Egyptians to the First Pharaohs. Oxford, 2000.

Murnane W. J. The Gebel Sheikh Suleiman Monument: Epigraphic Remarks. Journal of Near Eastern Studies. 1987. 46. Pp. 282-285.

Muzzolini A. Les images rupestres du Sahara. Toulouse, 1995.

Needler W. A Rock-Drawing on Gebel Sheikh Suliman (near Wadi Halfa) Showing a Scorpion and Human Figures. Journal of the American Research Center in Egypt. 1967. 6. Pp. 87-91.

Nordström H.-A. The Nubian A-Group: Perceiving a Social Landscape. Kendall T. (ed.). Nubian Studies 1998. Boston, 2004. Pp. 134-144.

O’Mara P. F. The Palermo Stone and the Archaic Kings of Egypt. La Canada, 1979.

Reisner G. A. The Archaeological Survey of Nubia. Report for 1907-1908. Vol. 1. Archaeological Report. Cairo, 1910.

Rögl F. von, Steininger F. F. Vom Zerfall der Tethys zu Mediterran und Paratethys. Die neogene Paläogeographie und Palinspastik der zirkum-mediterranen Raumes. Annalen des Naturbistorischen Museums in Wien. 1983. 85/A. S. 135-163.

Rouchy J. M., Caruso A. The Messinian Salinity Crisis in the Mediterranean Basin: A Reassessment of the Data and An Integrated Scenario. Sedimentary Geology. 2006. 188-189. Pp. 35-67.

Roveri M., Bertini A., Cosentino D., Stefano A. di, Gennari R., Gliozzi E., Grossi F., Iaccarino S. M., Lugli S., Manzi V., Taviani M. A High-Resolution Stratigraphic Framework for the Latest Messinian Events in the Mediterranean Area. Stratigraphy. 2008. 5. Pp. 323-342.

Said R. The Geological Evolution of the River Nile in Egypt. Rzóska J. (ed.). The Nile, Biology of an Ancient River. The Hague, 1976. Pp. 2-4.

Said R. The Geological Evolution of the River Nile. New York, 1981. 
Said R. The Geology of Egypt. New York, 1962.

Said R. The River Nile: Geology, Hydrology, and Utilization. Oxford, 1993.

Sandford K. S., Arkell W. J. Prehistoric Survey of Egypt and Western Asia, Paleolithic Man and the Nile Fayum Divide. A Study of the Region during Pliocene and Pleistocene Times. Chicago, 1929.

Sayce A. H. Karian, Egyptian and Nubian-Greek Inscriptions from the Sudan. Proceedings of the Society of Biblical Archaeology. 1910. 32. Pp. 261-268.

Schäfer H. Ein Bruchstück altägyptischer Annalen. Berlin, 1902.

Seidlmayer S. J. Town and State in the Early Old Kingdom. A View from Elephantine. Spencer A. J. (ed.). Aspects of Early Egypt. London, 1996. Pp. 108-127.

Selley R. C. (ed.). African Basins. Amsterdam, 1997.

Shahin M. Hydrology of the Nile Basin. Amsterdam, 1985.

Smith G. E. The Ancient Egyptians and the Origin of Civilization. London, New York, 1923.

Smith G. E. The Influence of Racial Admixture in Egypt. Eugenics Review. 1916. 7. Pp. 163-183.

Somaglino C., Tallet P. Une campagne en Nubie sous la Ire dynastie: la scène nagadienne du Gebel Sheikh Suleiman comme prototype et modèle. Nehet. Revue numérique d'égyptologie (Paris-Sorbonne - Université Libre de Bruxelles). 2014. 1. Pp. 1-46.

Somaglino C., Tallet P. Gebel Sheikh Suleiman: a First Dynasty Relief after All... Archéo-Nil. 2015. 25. Pp. 122-134.

Storemyr P. A Prehistoric Geometric Rock Art Landscape by the First Nile Cataract. Archéo-Nil. 2009. 19. Pp. 121-150.

Storemyr P. Overview of Rock Art, Stone Alignments, Desert Routes and a Possible Hermitage at the West Bank of Aswan. Bloxam E., Heldal T., Storemyr P. (eds). Characterisation of Complex Quarry Landscapes: An Example from the West Bank Quarries, Aswan. Trondheim, 2007. Pp. 163-181.

Storemyr P., Bloxam E., Heldal T., Kelany A. Ancient Desert and Quarry Roads on the West Bank of the Nile in the First Cataract Region. Förster F., Riemer H. (eds.). Desert Road Archaeology in Ancient Egypt and Beyond. Köln, 2013. Pp. 399-423.

Storemyr P., Kelany A., Negm M. A., Tohami A. More 'Lascaux Along the Nile'? Possible Late Palaeolithic Rock Art in Wadi Abu Subeira, Upper Egypt. Sahara. 2008. 19. Pp. 155-158.

Török L. Between Two Worlds. The Frontier Region between Ancient Nubia and Egypt 3700 BC - AD 500. Leiden, 2009.

Urk. I = Sethe K. Urkunden des Alten Reichs. Bd. I. Leipzig, 1933.

Valbelle D. Les Neuf Arcs: l'égyptien et les étrangers de la prébistoire à la conquête d'Alexandre. Paris, 1990.

Vermeersch P. M., Neer W. van, Gullentops F. El Abadiya 3, Upper Egypt, a Late Palaeolithic Site on the Shore of a Large Nile Lake. Kroeper K., Chlodnicki M., Kobusiewicz M. (eds.). Archaeology of Early Northeastern Africa. Poznan, 2006. Pp. 375-424.

Vermeersch P. M., Neer W. van. Nile Behaviour and Late Palaeolithic Humans in Upper Egypt during the Late Pleistocene. Quaternary Science Reviews. 2015. 130. Pp. 155-167.

Verschuren D., Sinninghe Damsté J. S., Moernaut J., Kristen I., Blaauw M., Fagot M., Haug G. H., CHALLACEA Project Members. Half-Precessional Dynamics of Monsoon Rainfall Near the East African Equator. Nature. 2009. 462. Pp. 637-641.

Vinogradov A. K. On the Rendering of the Toponym \&Astj. Chronique d'Égypte. 2000. 75. Pp. 223-234.

Walker M., Johnsen S., Rasmussen S. O., Popp T., Steffensen J.-P., Gibbard P., Hoek W., Lowe J., Andrews J., Björck S., Cwynar L. C., Hughen K., Kershaw P., Kromer B., Litt T., Lowe D. J., Nakagawa T., Newnham R., Schwander J. Formal Definition and Dating of the GSSP (Global Stratotype Section and Point) for the Base of the Holocene Using the Greenland NGRIP Ice Core, and Selected Auxiliary Records. Journal of Quarternary Science. 2009. 24. Pp. 3-17.

Wendorf F. A. Summary of Nubian Prehistory. Wendorf F. A. (ed.). The Prehistory of Nubia. Vol. 2. Dallas, 1968. Pp. 1041-1059. 
Wenke R. J., Buck P. E., Hanley J. R., Lane M. E., Long J. E., Redding R. R. The Fayum Archaeological Project: Preliminary Report of the 1981 Season. American Research Center in Egypt Newsletter. 1983. 122. Pp. 25-40.

Wilkinson T. A. H. Early Dynastic Egypt. London, 1999.

Williams B. B. Forebears of Menes in Nubia: Myth or Reality? Journal of Near Eastern Studies. 1987. 46. Pp. 15-26.

Williams B. B. The Lost Pharaohs of Nubia. Archeology. 1980. 33, 5. Pp. 14-21.

Williams M. A. J., Adamson D. A., Prescott J. R., Williams F. M. New Light on the Age of the White Nile. Geology. 2003. 31. Pp. 1001-1004.

Williams M. A. J., Talbot M. R., Aharon P., Salaam Y. A., Williams F. M., Brendeland K. I. Abrupt Return of the Summer Monsoon 15,000 Years Ago: New Supporting Evidence from the Lower White Nile Valley and Lake Albert. Quaternary Science Reviews. 2006. 25. Pp. 2651-2665.

Williams M. A. J., Williams F. M. Evolution of Nile Basin. Williams M. A. J., Faure H. (eds.). The Sahara and the Nile: Quaternary Environments and Prehistoric Occupation in Northern Africa. Rotterdam, 1980. Pp. 207-224.

Williams M. A. J., Williams F. M., Duller G. A. T., Munro R. N., El Tom O. A. M., Barrows T. T., Macklin M., Woodward J., Talbot M. R., Haberlah D., Fluin J. Late Quaternary Floods and Droughts in the Nile Valley, Sudan: New Evidence from Optically Stimulated Luminescence and AMS Radiocarbon Dating. Quaternary Science Reviews. 2010. 29. Pp. 1116-1137.

Williams M. A. J. Late Pleistocene and Holocene Environments in the Nile Basin. Global and Planetary Change. 2009. 69. Pp. 1-15.

Williams M. A. J. The Nile Basin: Quaternary Geology, Geomorphology and Prehistoric Environments. Cambridge, 2019.

Winkler H. A. Rock-Drawings of Southern Upper Egypt. I. Sir Robert Mond Desert Expedition, Season 19361937. Preliminary Report. London, 1938.

Winkler H. A. Rock-Drawings of Southern Upper Egypt. II (Including 'Uwènât). Sir Robert Mond Desert Expedition, Season 1937-1938. Preliminary Report. London, 1939.

Woodward J., Macklin M., Fielding L., Millar I., Spencer N., Welsby D., Williams M. A. J. Shifting Sediment Sources in the World's Longest River: A Strontium Isotope Record for the Holocene Nile. Quaternary Science Reviews. 2015. 130. Pp. 124-140.

\section{Э^ектронные ресурсы / Electronic sources}

Storemyr P. The Little-Known Archaeology of Gharb Aswan, Upper Egypt. URL: https://perstoremyr.net/2013/02/27/the-little-known-archaeology-of-gharb-aswan-upper-egypt/ (Аата обращения 21.10.2019).

Storemyr P. The Palaeolithic Rock Art in Wadi Abu Subeira, Egypt: Landscape, Archaeology, Threats and Conservation. URL: https://per-storemyr.net/2012/05/01/the-palaeolithic-rock-art-in-wadiabu-subeira-egypt-landscape-archaeology-threats-and-conservation/ (Аата обращения 26.11.2019).

Williams B., Kleinitz C., Reshetnikova N., Unhammer O. The Gebel Sheikh Suleiman Monument. URL: https://www.academia.edu/34223600/The_Gebel_Sheikh_Suleiman_Monument (Аата обращения 06.10.2019).

Аробышевский С. В. О расах Аревнего Египта и Нубии. Антропогенез.py. URL: http://antropogenez.ru/zveno-single/302/ (Аата обращения 27.09.2019) 